\title{
Forest Biosecurity Systems and Processes: An Indian Perspective
}

\section{OPEN ACCESS}

Edited by:

Kimberly Wallin,

North Dakota State University,

United States

Reviewed by:

Angus J. Carnegie,

New South Wales Department

of Primary Industries, Australia

Gonzalo Martínez,

National Institute for Agricultural

Research (INIA), Uruguay

Sofia Boza,

University of Chile, Chile

${ }^{*}$ Correspondence:

K. V. Sankaran

sankarankv@gmail.com

Specialty section:

This article was submitted to Pests, Pathogens and Invasions,

a section of the journal

Frontiers in Forests and Global

Change

Received: 24 April 2021

Accepted: 23 August 2021

Published: 30 September 2021

Citation:

Gupta K and Sankaran KV (2021)

Forest Biosecurity Systems and Processes: An Indian

Perspective.

Front. For. Glob. Change 4:699950.

doi: 10.3389/ffgc.2021.699950

\section{Kavita Gupta ${ }^{1}$ and K. V. Sankaran²* \\ ${ }^{1}$ Indian Council of Agricultural Research (ICAR)-National Bureau of Plant Genetic Resources, New Delhi, India, ${ }^{2}$ Kerala Forest Research Institute, Thrissur, India}

Biological invasions continue unabated across the globe despite all efforts to manage the problem by implementing biosecurity regulations and associated management methods. In this context, this paper reviews the plant biosecurity legislation applicable to agriculture and forestry sectors in India to prevent/manage invasions, with the objective of identifying limitations in the legislation or lapses in implementing it and propose corrective measures. The legislation can be improved by: (1) revising and updating the Destructive Insects and Pests Act (1914) and Plant Quarantine Order 2003 and (2) establishing a National Sanitary and Phytosanitary Database Center to promote exchange of information. Establishing more plant quarantine stations with state-ofthe-art facilities and a Biosecurity and Trade Unit may support implementation of legislation. Some of main gaps in information and research in biosecurity are identified. The plant biosecurity legislation, though meant to be common, mainly addresses the agriculture sector; its application in the forestry context is currently scarce. Hence, it is suggested that India may enact forest biosecurity scrupulously especially in the context of introducing the REDD + strategy and a Forest Certification Scheme. It is proposed that an integrated pest management (IPM) system involving e-pest surveillance, establishment of pest-free areas and use of biocontrol may help tackle emerging pest threats. The use of new technologies for remote sensing and detection and mapping of vegetation may help bio-surveillance, forecasting, and monitoring of pests. However, successful implementation of all management options demands formation of an exclusive national policy to manage invasive alien species and an action plan governed by a single agency. To realize the plant biosecurity goals, India may also strengthen regional cooperation to: (1) harmonize regulations for sanitary/phytosanitary and plant quarantine/biosafety measures and (2) use a common pest risk analysis (PRA) for unknown pests in the region. Capacity-building of officials to identify risky goods and verify conformity with Import Health Standards is raised. Also, raising awareness on biosecurity among all stakeholders and involving them in implementing the legislation would be helpful. The proposed National Agricultural Biosecurity System and the Agricultural Biosecurity Bill currently considered by the Indian Parliament is expected to address the inadequacies.

Keywords: quarantine, forestry, pests, phytosanitary measures, bio-surveillance 


\section{INTRODUCTION}

Exchange of plants/planting material within and between countries carries an unintentional risk of introduction of alien pests or their more virulent strains into new regions (Kahn, 1989). There are several examples of harmful pests (alien insect pests, pathogens, and plants- based on IPPC criteria) introduced through this pathway that have led to serious biosecurity threats and related socio-economic consequences (Liebhold et al., 2012). Of late, the rapidity of development in various sectors across the globe has posed unprecedented biosecurity risks to human, animal, plant and environmental health (Fisher et al., 2012). It is widely accepted that globalization, climate change, pollution, and cutting-edge biological innovations such as genetic engineering have the potential to impact all life forms and our environment in different ways. Further, the advent of World Trade Organization (WTO) and liberalization of global trade in commodities and services since 1995, have opened up new avenues for trade and transport resulting in several new challenges. The foremost among these is the risk of invasive alien species (IAS) into countries/regions with serious impacts on the economy, the environment and good quality of life of people (Pyšek et al., 2020).

Some of the notable examples of IAS impacts are the Irish potato famine (Saville et al., 2016), Dutch elm disease, chestnut blight (Fisher et al., 2012), coffee rust disease (McCook, 2006), and bunchy top of banana (Wardlaw, 1961). The threat of plant disease has not abated, in fact, it was enhanced by resource-rich farming practices and microbial adaptation to new ecosystems, brought about by trade and transportation (Grünwald et al., 2008; Bilodeau et al., 2019), and fluctuations in climate (Brown and Hovmoller, 2002). Liebhold et al. (2012) estimated that almost $70 \%$ of the alien forest insects and pathogens established in the US between 1860 and 2006 most likely entered through imported live plants.

Another challenge is the introduction of living modified organisms (LMOs) and genetically modified organisms (GMOs) which call for proper risk analysis and risk management before release. Climate change has been shown to alter the habitat and aid in the spread of known pests and introduction of new pests (Anderson et al., 2004; Sturrock et al., 2011). Also, worldwide, there is a continuing threat of bioterrorism. The recent occurrence and international spread of diseases such as the COVID-19, avian influenza and the $\mathrm{Ug}_{99}$ stem rust of wheat are serious concerns to human, animal and plant safety, respectively.

Against this background, ensuring "biosecurity" has emerged as one of the most crucial issues worldwide requiring countries to implement policies and improve technical capabilities to detect, prevent and manage threats from alien species on the life and health of humans, animals and plants. In a broader sense, "biosecurity" encompasses food safety, zoonoses, the incursion and management of invasive alien plants and pests of animals and plants and the introduction and release of LMOs or GMOs. It is a strategic and integrated approach involving decisive linkages between various sectors along with harmonizing and incorporating national biosecurity systems and controls to draw the benefit of synergies across sectors (FAO, 2007). It is also envisaged to improve the country capacity to safeguard human and animal health, agricultural production and livelihood, protect the forests and the environment and avoid biological risks. In addition, biosecurity measures would equip countries to meet obligations for compliance with the international agreements (e.g., International Plant Protection Convention-IPPC) and trade under the Agreement for Application of Sanitary and Phytosanitary Measures in food, plants and plant products.

There are several pathways for introduction of an alien pest into a new locality/region. These include (a) the host itself acting as a carrier of an invasive pest; (b) untreated packing materials which may carry seeds, eggs and spores; (c) birds and insect vectors; (d) wind which can transmit pests to long distances or (e) intentional and illegal transportation to use pests for different purposes including as bioweapons (Khetarpal et al., 2009). Adoption of proper quarantine measures can take care of the first two pathways. The next two pathways are not easy to control and this is a major impediment to exclude invasive alien species. The last one calls for constant vigil and preparedness but failure is not uncommon. International movement of IAS through global trade has posed a serious threat to biosecurity necessitating creation of appropriate legislations to regulate import/export of goods and commodities.

Plant quarantine is a legislative measure to prevent accidental introduction of IAS, through transfer of planting materials, plant products, soil, and living organisms, which can harm agriculture, forestry, and other ecosystems in the receiving country/region. It also includes measures to prevent the establishment and spread of such species if introduced inadvertently. The impacts of thus introduced invasive alien pests on agriculture and forestry species in the India are discussed by Khetarpal (2004); Gupta et al. (2005), and Khetarpal et al. (2009).

In the forestry context, the main concern of biosecurity is the threat posed by IAS. Apart from chestnut blight (Hepting, 1974) and Dutch elm disease (Jacobs et al., 2004), Asian long horned beetle (Meng et al., 2015), the gypsy moth (Doane and McManus, 1981), emerald ash borer (Valenta et al., 2016), and alien weeds such as Lantana camara L. (Bhagwat et al., 2012), Mikania micrantha Kunth (Ellison et al., 2017), Chromolaena odorata (L.) King \& H. Rob. (Gautier, 1992), and Miconia calvescens DC. (Peh, 2010) are also known to impact forest ecosystems heavily. Forest biosecurity issues encompass forest protection and phytosanitary measures, impact of introduced forest trees on ecosystems and native species and the introduction of new genotypes including GMO’s (Cock, 2003).

The main pathways of introduction of IAS which pose a threat to forest biodiversity include import/export of wood packing materials, unprocessed timber, contaminated forest seeds and germplasm (Cock, 2003; Meurisse et al., 2019). Prevention of incursions through pre-border biosecurity measures is the most efficient strategy to avoid an IAS. Managing pathways of introduction through strict implementation of quarantine measures at the border are equally effective. For those 
species which have already entered a country/region and the spread is limited at the time of detection, rapid management response has proved to be useful. However, managing a species which has already spread and established in forests is a challenge where integrated measures including biocontrol may be attempted.

Developed countries (e.g., Australia, New Zealand, United States) are putting all out efforts by implementing preborder, border, and post border biosecurity measures to keep IAS away (Invasive Species Council, Australia, 2016 ${ }^{1}$; Government of New Zealand, 2018²; US Department of Agriculture [USDA]Animal and Plant Health Inspection Service [APHIS], 2020). On the contrary, lack of awareness among stakeholders, poor coordination in implementing legislations, deficiency in quarantine measures, excessive dependence on biological resources and poor technical capacity frustrates attempts at maintaining biosecurity in developing economies (Banerjee et al., 2021). Whichever be the case, incursion of alien species and threats to biosecurity continue unabated across the globe, helped by free trade and inefficient inspection at the borders (Santini et al., 2013; Faulkner et al., 2020).

In India, regular surveillance for forest pests has not been given due importance and hence early detection of IAS and rapid response actions are infrequent. Information on pest occurrence is mostly obtained through informal observations by foresters and occasional surveys carried out by research organizations such as the Kerala Forest Research Institute (Sharma et al., 1985; Mohandas et al., 1990) and institutions under the Indian Council of Forestry Research and Education (Singh et al., 2004; Jacob et al., 2007).

In order to prevent invasion of alien pests into forest ecosystems in the country, the Plant Quarantine Order 2003 of the Govt. of India has notified a total of 152 insects, 67 fungi, five bacteria, three viruses, one nematode, one pest of unknown etiology (Mundulla yellows- Mundulla yellows dieback), and one parasitic plant (Arceuthobium pusillum Peck,-eastern dwarf mistletoe) as regulated pests associated with various forest species and associated material including wood being imported into India. A total of 57 plant species (not specific to forests) are also notified as regulated pests. These have been identified based on pest risk assessments carried out by the National Plant Protection Organization Government of India [GOI] (2003). ${ }^{3}$

A literature survey revealed the occurrence of over 80 invasive alien plants, 14 insect pests and 11 plant pathogens affecting natural and planted forests in the country (Government of India [GOI], 2007; Sankaran and Suresh, 2013; Sankaran et al., 2013). However, this list is far from complete for want of country-wide surveys. The major invasive alien pests which pose potential threats to forest ecosystems in India include Miconia calvescens, Piper aduncum L. (plants), Cryphonectria parasitica (Murrill) M.E. Barr, Ophiostoma novo-ulmi Brasier, Ceratocystis fagacearum (Bretz) J. Hunt and Fusarium circinatum Nirenberg and O'Donnell (plant pathogens), and insects viz.,

\footnotetext{
${ }^{1}$ https://invasives.org.au/strategy-invasive-species-australia

${ }^{2}$ https://www.mpi.govt.nz/biosecuritynz

${ }^{3}$ https://plantquarantineindia.nic.in/PQISPub/pdffiles/pqorder2015.pdf
}

Agrilus planipennis Fairmaire (Emerald ash borer), Anoplophora glabripennis Motschulsky (Asian long- horned beetle), and Popillia japonica Newman (Japanese beetle). The pine wilt nematode Bursaphelenchus xylophilus (Steiner and Bührer) Nickle is an impending threat to pine plantations.

The increasing number of new incursions into the country indicate that the existing biosecurity regulations are either not implemented properly or they lack proper provisions to prevent/manage invasions. This paper is an attempt to review the legislation and offer corrective measures so that the biosecurity goals are achieved. Forest biosecurity is dealt with as a part of agricultural biosecurity in India. Hence, information provided in this paper is mainly on plant biosecurity measures in an agricultural context since examples of biosecurity measures applied in the forestry sector are rare. A similar situation exists in Australia where the biosecurity agencies are largely agri-centric and the forest industry is reluctant to involve in bio-security (Carnegie et al., 2018). But, the forest biosecurity system in India is getting more relevant and obligatory as this sector currently faces new challenges as discussed in this paper.

\section{CURRENT STATUS OF PLANT BIOSECURITY REGULATIONS IN INDIA}

\section{Legislative Framework}

The first quarantine law approved in India was the Destructive Insects and Pests (DIP) Act in 1914 Government of India [GOI] (1992). ${ }^{4}$ In 1936, a gazette notification on rules for regulating the import of plants etc. into India was issued to implement the plant quarantine law. Over the past $>100$ years, the DIP Act was reviewed and modified continually, more so recently, to take care of the emerging challenges of pest risk due to the liberalized trade under the WTO (after 1995).

To regulate the import of plants, fruits and seeds (PFS) into India, the Govt included the PFS Order in the DIP Act in 1984 (reviewed in 1989). Also, a new Policy on Seed Development was approved in 1988 which proposed major changes in quarantine regulations. The new policy had an impact on the import of seeds/planting materials of crops such as rice, wheat, other cereals, pulses, oil seeds, vegetables, ornamentals, fruit, and flower crops. The revised PFS Order, 1989 made it mandatory that the plant quarantine requirements may not be compromised while relaxing import. At the national level, the DIP Act contained rules and regulations for preventing the introduction of pests causing harm to arable crops and forest species within the country. But there was no policy or legislation to control movement of invasive alien plants in the Act (Banerjee et al., 2021).

India became a party to the International Plant Protection Convention (IPPC) in 1956. The IPPC aims to develop international cooperation among various countries to "prevent the introduction and spread of regulated pests along with international movement of plants and planting material"

\footnotetext{
${ }^{4}$ https://plantquarantineindia.nic.in/PQISPub/docfiles/dip_act.htm
} 
(FAO, 2011). ${ }^{5}$ Under the IPPC regulations, each member country is required to establish a national plant protection organization (NPPO) to implement the regulations approved by it.

India currently proposes to expand its trade in plants/plant products but to proceed with this proposal, it is necessary to develop national standards for phytosanitary activities which must comply with international regulations. The Plant Quarantine (Regulation of Import into India) Order 2003 Government of India [GOI], 2003; (see text footnote 3) was approved to take care of these requirements. This order made it mandatory that pest risk analysis (PRA) may be conducted on all seed/planting material for import to ensure freedom from quarantine pests. The PQ Order also enhanced the scope of plant quarantine regulations. Its key features are quoted below.

- "Schedule VIII which calls for prohibition on import of commodities with contamination of weed/alien species as per restriction on import of packing material of plant origin unless treated.

- Provisions included for regulating the import of soil, peat, and sphagnum moss, germplasm/GMOs/transgenic material for research purpose, live insects/microbial cultures and biocontrol agents and import of timber and wooden logs.

- Plant imports have been categorized as

- Prohibited plant species (Schedule IV); forestry species listed in the schedule are given in Table 1;

(a) Restricted species permitted only by authorized institutions (Schedule V);

(b) Restricted species permitted with additional declarations of freedom from regulated pests and subject to specified conditions including treatments, post-entry quarantine treatments etc. (Schedule VI) and;

(c) Plant material imported for consumption/industrial use permitted with a standardized Phytosanitary Certificate (Schedule VII).

(d) Additional declarations have been specified in the PQ Order for import of 699 plant commodities with specific lists of more than $>1,000$ quarantine pests and 57 species of weeds.

- Notified points of entrance increased to 182 .

- Certification fee and inspection charges have been rationalized."

Eighty-eight amendments to the PQ Order have been reported to the WTO until April 2021. The list of crops under the Schedules IV, V VI, and VII have been enhanced. The updated list under Schedule VI and VII now have 700 and 519 crops and commodities, respectively. ${ }^{6}$

The only regulation which emphasized control and eradication of invasive alien species in natural forests in India was the "Intensification of Forest Management Scheme" issued by the Ministry of Environment, Forests and Climate Change (Government of India [GOI], 2009). It also included a stipulation for support to state research institutions to conduct research on

\footnotetext{
${ }^{5}$ http://www.ippc.org

${ }^{6} \mathrm{https} / /$ plantquarantineindia.nic.in/PQISPub/pdffiles/pqorder2015.pdf
}

management of IAS. However, this initiative was not successful in meeting its goals due either to barriers in implementing it or a lack of awareness on invasive alien species at the management level (Kannan et al., 2013). Moreover, the Wildlife Act (1972) prevented the harvesting and removal of any plant and animal material, whether invasive or not, from the protected areas in India. However, the Hon. the Supreme Court of India ordered constitution of a Central Empowered Committee (CEC) to look into the issues which provided a mechanism for review and allow flexibility on a case-by-case basis. Thus, there is an option for exemptions which the stakeholders may use for managing invasive alien species in protected areas (Kannan et al., 2013).

\section{Infrastructure}

In India, agriculture and crop production, including plant protection from indigenous pests, is the responsibility of the Governments of individual states. However, protection of wildlife and animals, forests etc. falls under the Concurrent List that give powers to both the central (federal) and state Governments. However, should there be a conflict concerning laws passed by Parliament and state Legislatures on the same subject, the Constitution upholds the law approved by the central Government over the state law. The central government (Ministry of Agriculture, Department of Agriculture, Cooperation, and Farmers Welfare) supplements state's efforts in pest surveillance and management by disseminating innovative pest management techniques. Plant quarantine and locust control in the scheduled desert area, being inter-state and international subjects, are managed by the central government. The national infrastructure is empowered for proper implementation of the quarantine regulations framed for the country. The Directorate of Plant Protection, Quarantine and Storage (DPPQS) of the Ministry of Agriculture and Farmers Welfare is the uppermost body for the execution of plant quarantine regulations [the National Plant Protection Organization (NPPO) for India]. The DPPQS has a network of 73 plant quarantine stations at different seaports, airports and land borders at the national level 1 (Figure 1). Two major types of materials are imported under the PQ Order, 2003: (a) bulk consignments for sowing/planting and consumption, and (b) small quantities of germplasm samples for research. The clearance of consignments under the first category is the responsibility of the Plant Quarantine Stations under the DPPQS.

Plant genetic resource exchange is regulated through ICAR-National Bureau of Plant Genetic Resources (NBPGR) functioning under the delegated powers of the Destructive Insect Pests Act, 1914 and the Plant Quarantine Order 2003 for import of various crops/plant species intended for research by both public and private sectors. It has laboratories with modern facilities in all the disciplines of plant protection (Plant Pathology, Entomology, Virology, Nematology, and Weed science) and a greenhouse complex (Bhalla et al., 2018). A National Containment Facility has also been established for quarantine testing of transgenics (Gupta et al., 2007). ICAR-NBPGR also has a quarantine 
TABLE 1 | List of forest plants/planting materials and countries from where import is prohibited along with justifications listed in SCHEDULE-IV of the PQ order.

\begin{tabular}{|c|c|c|c|}
\hline $\begin{array}{l}\text { Plant } \\
\text { species/variety }\end{array}$ & Categories of plant material & Prohibited from countries & $\begin{array}{l}\text { Justification for prohibition - to avoid the } \\
\text { pests/pathogens shown below }\end{array}$ \\
\hline $\begin{array}{l}\text { Forest/plantation } \\
\text { tree species } 1 . \\
\text { Chestnut } \\
\text { (Castanea spp.) }\end{array}$ & $\begin{array}{l}\text { Seeds/fruits/grafts and other } \\
\text { planting material }\end{array}$ & $\begin{array}{l}\text { North America (United States } \\
\text { and Canada) }\end{array}$ & $\begin{array}{l}\text { Chestnut blight or canker (Cryphonectria } \\
\text { parasitica) -American strain. }\end{array}$ \\
\hline $\begin{array}{l}\text { 2. Elm (Ulmus } \\
\text { spp.) }\end{array}$ & Plants/planting material & $\begin{array}{l}\text { North America (United States } \\
\text { and Canada), Europe and } \\
\text { Russia }\end{array}$ & $\begin{array}{l}\text { Dutch elm disease pathogen (Ophiostoma ulmi) } \\
\text {-American and European strains, elm mottle } \\
\text { virus, elm bark beetles (Scolytidae), elm phloem } \\
\text { necrosis (Phytoplasmas) and white -banded } \\
\text { elm leaf hopper (Scaphoidous luteolus) -vector } \\
\text { of elm phloem necrosis. }\end{array}$ \\
\hline $\begin{array}{l}\text { 3. Oak } \\
\text { (Quercus spp.) }\end{array}$ & Seeds/root grafts & United States & $\begin{array}{l}\text { Oak wilt pathogen (Bretziella fagacearum) and } \\
\text { oak bark beetles (Pseudopityophthorus spp.) }\end{array}$ \\
\hline \multirow[t]{2}{*}{$\begin{array}{l}\text { 4. Pine (Pinus } \\
\text { spp.) and other } \\
\text { coniferous } \\
\text { species }\end{array}$} & Seeds/saplings & $\begin{array}{l}\text { North America (Canada, } \\
\text { United States, and Mexico) }\end{array}$ & $\begin{array}{l}\text { Pine rusts Stalactiform blister rust (Cronartium } \\
\text { coleosporioides), Comandra blister rust } \\
\text { (C. comandrae), sweet fern blister rust } \\
\text { (C. comptoniae), Southern fusiform rust } \\
\text { (C. fusiforme), Western gall rust (Cronartium } \\
\text { harknessii), Brown spotneedle blight } \\
\text { (Lecanosticta acicola) Seedling die-back and } \\
\text { pitch canker (Fusarium moniliforme f.sp. } \\
\text { subglutinans) and Needle cast (Lophodermium } \\
\text { spp.) }\end{array}$ \\
\hline & Wood with bark & $\begin{array}{l}\text { North America (Canada and } \\
\text { United States), Asia (China, } \\
\text { Hong Kong, Japan, Korea, } \\
\text { Republic of Taiwan) }\end{array}$ & $\begin{array}{l}\text { Pine wood nematode (Bursaphelenchus } \\
\text { xylophilus) }\end{array}$ \\
\hline
\end{tabular}

unit at its Regional Station, Hyderabad that primarily undertakes quarantine of the samples for export from the International Crop Research Institute for Semi-arid Tropics (Chakrabarty et al., 2005).

\section{Risks Associated With Imports}

Of the two categories of material being imported, risk of IAS is maximum with bulk imports for sowing/planting as careful inspection and treatment are tricky. Quarantine processing in such cases is limited to samples derived from the bulk and based on the results of inspection, the consignment is either detained or released after suitable treatment. The wood import also falls into this category. In comparison, the bulk import for consumption poses minimum threats. However, plant samples meant for research pose a huge threat as they usually comprise germplasm/landraces/wild relatives of plants and are highly likely to carry diverse pest biotypes/races/strains. Also, the risks are higher while importing seeds due to infections from superficial contamination. Import of vegetative propagules pose a much higher degree of risk compared to seeds. The sample size for quarantine processing of bulk and small samples are different but the techniques used for detecting different types of pests are the same.

In the context of risks perceived from import of wood packaging material or other wood products, India has national standards for "Quarantine Treatments and Application Procedures viz., Methyl Bromide Fumigation" and "Guidelines on Certification of Forced Hot-air Treatment Facilities for Wood Packaging Material” in line with ISPM 15. The latter was developed to ensure that approved measures are applied consistently to the wood packaging material and to facilitate proper assessment and certification of heat treatment facilities (Government of India [GOI], 2011). ${ }^{7}$

\section{Interceptions in Imported Material}

India intercepted a large number of insect pests and plant pathogens during quarantine processing of imported bulk consignments (Government of India [GOI] (2011) see text footnote 7), wood and germplasm and other research material over the last several years (Khetarpal and Gupta, 2008). These included (1) pests that are unknown to occur in the country; (2) new races/biotypes/strains of pests; (3) pests affecting a new host; (4) those from a country where these species are not known to occur; (5) a pest species new to science; (6) a cosmopolitan species which occurs on several hosts in India. These interceptions, especially of pests and their strains new to India (Categories 1 and 2), imply the importance of quarantine measures in preventing the introduction of harmful alien pests. Pests included in the third and fourth categories are important to quarantine interceptions since PRA cannot reveal records of the pest/host/country. Similarly, the fifth category of pest is also important since it forms a species new to science. The sixth category of pests with a wide host range are also important in the sense that they may turn invasive under suitable biotic and abiotic environments and increase its biological range.

\footnotetext{
${ }^{7}$ http://plantquarantineindia.nic.in
} 


\section{Threats From Emerging Pests and Diseases}

The threat of alien pests is of great concern for biosecurity especially in the current scenario of liberalized trade. Another concern is that the indigenous pests may become virulent and the response of hosts may also change with the global changes in climate and land use. Also, a resurgence of pest problems along with the changes in cropping system cannot be neglected in our endeavor to sustain crop production, forest health and food security. In addition, several resistant strains of pests have evolved as a result of excessive use of chemical pesticides which call for the constant need of improved and more ecofriendly mitigative measures. Finally, assessing risks due to the GM technology in forest trees is challenging since there are no approved protocols for assessment.

\section{RECOMMENDATIONS FOR IMPROVEMENT OF THE NATIONAL BIOSECURITY SYSTEM}

The recommendations below are based on a critical assessment of the current legislation and identification of inadequacies in it and imperfections in implementation. Adoption of these recommendations is apparently feasible if accepted by the policy makers, and they are expected to improve biosecurity conservation.

\section{Legislation}

The Destructive Insects and Pests Act (DIP Act), 1914 and the PQ Order 2003 cover import of plants/plant products based on risk assessments and management. However, there is a need to strengthen the provisions in the act as discussed below.

- The DIP Act is an old legislation and subsidiary to the Sea and Customs Act which does not give adequate powers to the Quarantine Officials to deport, destroy or confiscate the consignment or book them under the Indian Penal Code. Regulations need to be modified to empower the quarantine staff as discussed above and the provisions to import plants are to be strengthened to avoid inadvertent introduction of IAS (Gupta and Agarwal, 2016).

- Although the DIP Act has the provisions for inter-state or domestic plant quarantine, there are no supporting clauses for enforcing these resulting in spread of IAS within the country.

Though the DIP Act and PQ order are designed to take care of import of harmful pests, the main hurdle in enacting and implementing regulations to prevent/manage IAS in India is that the country lacks an exclusive national policy/legislation and an action plan to deal with invasive alien species across sectors (Banerjee et al., 2021). Also, we may need a devoted nodal agency to implement IAS management activities instead of a multi-agency and multi-program approach (Khetrapal et al., 2017). In addition to the DIP Act and PQ order, there a number of supporting regulations at the state and administrative levels
Ministry of Agriculture \& Farmers Welfare

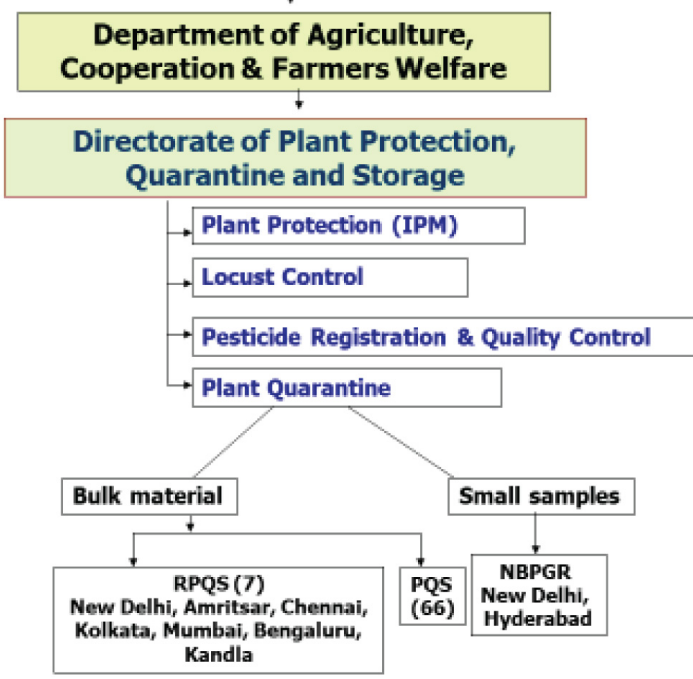

FIGURE 1 | The DPPQS organizational chart.

which contain provisions for prevention and/or management of IAS (Kishwan et al., 2007). However, none of these have yielded the expected results. Hence, it is suggested that India may develop a national policy devoted to tackle IAS issues and entrust implementation of the regulations with a single agency.

\section{Infrastructure}

\section{Establishment of More Plant Quarantine Stations}

Government of India has notified more than 183 International Entry Points which are managed by only 73 functional Plant Quarantine (PQ) Stations. The agricultural/forestry goods imported through these entry points are required to be monitored by plant quarantine stations with state-of-the-art facilities. This requires strengthening of the existing PQ Stations with additional human and infrastructural resources especially in view of the rapid increase in the quantum of international trade. Technical knowhow for pest monitoring and surveillance, pesticide registration and testing systems needs to be developed further and molecular diagnostic facilities established at the regional plant quarantine stations to facilitate rapid and accurate diagnosis of plant pests. The use of X-ray scanner (organic type) is to be made mandatory at all major plant and animal quarantine stations to screen travel baggage for prohibited materials.

\section{Capacity Building and Modernization} Improvement of the Information Management System The information management system used by the plant and animal quarantine services in India promotes free exchange of information to help organizational and client needs. However, it would be helpful if a National Sanitary and Phytosanitary Database Centre is established for data management (data collection, warehousing, protection, and sharing) through computer networking with all plant 
and animal quarantine stations. The Plant Quarantine Information System (PQIS) recently launched by the DPPQS, is a good step in this direction. It is useful Government of India [GOI] (2011) (see text footnote 7) to importers and other stake holders to avoid official delays in securing permission for import, import release and issue of Phytosanitary Certificate for exports.

\section{Establishment of a Biosecurity and Trade Unit}

Establishment of a Biosecurity and Trade Unit with various Cells as discussed below would help proper implementation of plant biosecurity legislations.

- A Sanitary and Phytosanitary (SPS) Cell- which could deal with the requirements for import of plants and planting material in the SPS-WTO regime and fulfill all related formalities. It may examine WTO-SPS notifications from other countries, prepare India's SPS notifications for WTO and prepare market access claims and bilateral agreements with other countries (Khetarpal and Gupta, 2002).

- Cell for Risk Analysis for Import and Export and Market Access- to carry out PRA scientifically and apply Sanitary and Phytosanitary measures complying with the WTOSPS Agreement and IPPC standards (Gupta and Khetarpal, 2004). The cell can undertake all related functions and organize training in advanced plant quarantine techniques and harmonize these with international standards.

- Integrated Pest Surveillance and Rapid Response Cell- to ensure early detection of introduced pests through regular surveys and provide reliable information for PRA. The cell may monitor pest status in an area to support market access through "pest-free areas." Where necessary, the cell may constitute a "Rapid response" team to check and control the spread of plant diseases.

- A Biosystematics Cell- for quick identification of pests so that the operational staff at ports of entry could take quick decisions. The cell may include experts in all relevant fields. The Bureaux for Microorganisms and Insects (arthropods) of the Indian Council of Agricultural Research, may function as a resource base for correct identification of insect pests and plant pathogens using molecular and other modern techniques.

- An Emergency Disaster Management Cell- as an integrated unit with experts in biosecurity risk assessment to plan quick actions to combat pest menace in the event of an epidemic. The cell may involve experts in various disciplines to achieve this.

- A Human Resource Development Cell- to organize regular training on sanitary and phytosanitary measures, pest diagnostics and international standards/guidelines on biosecurity measures. The Cell may also sensitize policy makers and other stakeholders (including farmers, scientists and the staff of agriculture and forest departments) on the importance of food safety, good agricultural/forest practice, plant quarantine, and how any breach of biosecurity would impact all these. All local governance bodies may appoint trained personnel as biosecurity managers.

\section{Research Requirements}

Research results from areas given under can also help to achieve plant biosecurity goals.

1. Identification and classification of various agents challenging the biosecurity of agriculture, forestry, livestock, fisheries, and poultry based on perceived risk levels.

2. Increased use of irradiation, thermal treatment, and other non-chemical and eco-friendly techniques as mitigation measures in quarantine.

3. Development of user-friendly serological/molecular diagnostic protocols for prognostic detection of alien pests and their variants and GMOs/LMOs.

4. Development of digitized bio-systematic keys for identification of pests especially insects.

5. Surveillance of invasive pests using robust procedures to identify endemic pests so as to detect pest free areas and use IPM to manage IAS.

6. Develop models for risk analysis of invasive alien pests, pathogens, and plants.

7. Changes in the epidemiology of major forest pests and diseases in relation to climate change.

8. Factors affecting the survival of alien pests during different modes of transport, ways and means of their spread, presence of hosts at destination, chances of establishment, modes of their reproduction, survival, potential vectors, and natural enemies of the pest in the introduced area.

9. Simulated evaluation of mitigation options for epidemics/pandemics.

10. Management of indigenous pests which will have the potential to impact environmental health, biodiversity and good quality of life.

11. Development of a national database of established and potential invasive alien plants and pests and diseases of plants and options for their management.

\section{MANAGING SOME OF THE EMERGING PESTS IN INDIA}

\section{Integrated Pest Management}

Focusing on the judicious and regulated use of pesticides, the Government of India has approved IPM as the main approach for plant protection since 1985. Based on this, employing an e-pest surveillance program utilizing GPS tools, establishment of pest free areas, promotion of biological control of pests and development of IPM packages would be of immense help in dealing with the new pests (Government of India [GOI], 2016a).[GOI] ${ }^{8}$

\footnotetext{
${ }^{8} \mathrm{http}: / /$ ppqs.gov.in/divisions/integrated-pest-management
} 


\section{Locust Control and Research}

The Locust Warning Organization (LWO) monitors and controls locust over an area of 200, $000 \mathrm{~km}^{2}$ of the Scheduled Desert Area (SDA) in parts of Rajasthan, Gujarat and Haryana states. Remote sensing data are currently being used to prepare vegetation maps (Government of India [GOI], 2016b) ${ }^{9}$ to improve locust monitoring and forecasting. However, to develop an effective locust control system, laboratory facilities need to be modernized and trained human resources may be deployed.

\section{Insecticides Act, 1968}

India is signatory to the FAO Code of Conduct on the Distribution and Use of Pesticides and is implementing its stipulations. The Insecticide Act, 1968, approved by the Govt. of India, regulates the import, manufacture, sale, transport, distribution and use of pesticides in order to prevent risk to human beings and animals and confirm the supply of quality pesticides. A new legislation, namely, the Pesticides Management Bill, 2020 has been introduced in the Indian Parliament in March 2020 with the aim of providing a more effective regulatory framework to take care of all issues concerning production and use of pesticides (Government of India [GOI], 2020). ${ }^{10}$

\section{THE NEED OF REGIONAL COOPERATION FOR BIOSECURITY}

Protection of plant biosecurity in India calls for regional collaboration with countries with which India shares contiguous boundaries. Also, collaboration among South Asian Nations (SANs) for creating a bio-secure region is necessary (Gupta and Dubey, 2016). The action points proposed are: (1) scrupulous implementation of quarantine at national boundaries of SANs; (2) harmonized sanitary and phytosanitary systems among SANs and adoption of regional standards; (3) training of staff from SANs on the epidemiology of high-risk diseases and the methodology of their diagnostics and management; (4) establishing an invasive alien pest database and sharing of information between and with other nations outside SAN's; (6) collaboration with Governments of SANs for effective implementation of the pest control strategies and (7) adopting policies which have proven effective against IAS-for e.g., for zoonotic diseases such as bird flu (Chowdhury et al., 2019).

The areas for regional collaboration and networking for plant biosecurity include:

\section{Regulatory Frameworks}

- Harmonize plant quarantine/biosafety regulations in the region in line with the norms of countries in the European Union framed by EPPO to categorize pests as A1 (not known to occur in EU) and A2 (known to occur in specific countries of EU) to facilitate trade among countries

\footnotetext{
${ }^{9} \mathrm{http} / /$ ppqs.gov.in/divisions/locust- control-research/locust-plagues-andupsurges

${ }^{10} \mathrm{https} / / /$ prsindia.org/billtrack/the-pesticide-management-bill-2020
}

within and outside the region without compromising the norms of biosecurity.

- Develop common quarantine regulations and updating these based on the norms prescribed by the IPPC. The development of common biosafety regulations in line with the Cartagena Protocol on Biosafety ${ }^{11}$ (Convention on Biological Diversity [CBD], 2000) could also be considered.

\section{Quarantine for Transboundary Movement of Plants/Planting Material}

- Countries with expertise to carry out quarantine of specific plant species/pests may take up that task on behalf of other member countries in a network mode. Specific laboratories may be accredited to carry out this.

- Improved post-entry quarantine facilities in developed countries within the region may be used to cater to the needs of the entire region to prevent introduction of alien species. Containment facilities may also be shared for biosafety testing of alien pests/pathogens and biocontrol agents.

- Countries with contiguous borders may develop programs for eradication and declaration of pest free areas within the region which would allow continuous surveillance, monitoring and eradication of IAS in countries where they have not spread.

\section{Risk Analysis}

Employing a common PRA for plants, insect pests and plant pathogens of quarantine significance to the region would be useful. To implement this, each country may survey the occurrence and distribution of invasive pests of agricultural crops/forests common to the region and share the information.

\section{Identifying Areas for Collaborative Research and Deploying Human Resources}

- Areas for collaborative research may be identified especially on topics such as etiology of unknown and emerging diseases, alternatives to methyl bromide (MB) fumigation etc. in view of the lack of authentic scientific information and resources in the region.

- Biosafety evaluation for an approved transgenic event conducted by one country may be endorsed by other countries to avoid duplication of testing (especially for testing allergy and toxicity). However, some tests which need to be carried out in the host environment (e.g., for gene flow studies), may be specific but these may be shared.

- A computerized database on status of insect pests and plant pathogens and their strains present in different countries of the region may be developed, updated regularly to include new records and shared.

- Regular training programs to strengthen research capabilities of staff and training for trainers may be conducted at the regional level.

\footnotetext{
${ }^{11}$ https://bch.cbd.int/protocol/
} 


\section{NEED OF A HARMONIZED AND INTEGRATED APPROACH TO SUSTAIN PLANT BIOSECURITY}

Biosecurity regulations in some countries, wherever it is separate for different sectors (e.g., life and health of animals and plants), are implemented in isolation ignoring the interdisciplinarity nature of biosecurity. But a harmonized and integrated approach involving different sectors would help to achieve the desired goals. As discussed earlier, a common legislation avoiding inconsistencies, overlaps and gaps between legislations may be framed and all sectors need to join hands to identify priorities for biosecurity and plan activities in a cooperative mode. An integrated plant biosecurity system would present a single interface to exporters/importers and allows for sharing of resources among different sectors.

Risk analysis and early warning systems are the most important unifying concepts in biosecurity cutting across different sectors which help to prevent IAS incursions. Risk analysis involves risk assessment, risk management and risk communication. International organizations such as the IPPC, Organization of International Epizootics (OIE), and different bodies dealing with biosecurity have adopted risk assessment as an essential tool in maintaining biosecurity (FAO, 2007). Biosecurity risk assessment estimates scientifically the risks to life and health due to the invasion of alien species. Prevention, elimination or management of those risks may require adoption of different strategies. The importance of science-based risk assessment to plant biosecurity has placed considerable technical demands on national organizations and relevant stakeholders. And, stakeholder participation is key to risk assessment and risk management and successful risk communication.

The National Commission on Farmers, India has recommended formation of a National Agricultural Biosecurity System (NABS) which aims at managing biological risks in an inclusive and cooperative mode. The functioning of NABS calls for cooperation and sharing of expertise of various organizations under different Ministries of the central Government. Integration of the system involving the most experienced officials would help to arrive at suitable decisions and frame guidelines for preventing entry, establishment and spread of IAS and to plan management actions. The integrated system is also expected to facilitate (a) timely handling of threats to biosecurity, (b) optimum utilization of resources, and (c) establishment of a systems approach to achieve desired results. It would also help sharing of national facilities and expertise across different disciplines and institutions.

\section{GLOBAL CONVERGENCE TO ACHIEVE BIOSECURITY}

The international Agreement on Application of Sanitary and Phytosanitary Measures of the WTO governs these measures in relation to international trade. The Codex Alimentarius Commission (Codex), the IPPC and OIE provide international standards for food safety, plant health, and animal health, respectively. Further, guidelines on the management of IAS have been developed by the SBSTTA of the CBD (Rana et al., 2004; Gupta et al., 2009). All these international agreements, organizations and programs form a loose international framework for biosecurity. Unfortunately, they are not fully free from sectorial approaches which frustrate effective functioning.

For example, Codex fixes the maximum residue level (MRL) or tolerance limits of various pesticides based on extensive toxicological studies and trials. MRLs are very important in international trade as excessive residues are not accepted by importing countries and act as non-tariff barriers. Application of pesticides is a phytosanitary requirement to manage the pest. However, the residue left by these applications is a sanitary issue which needs to be below the MRLs prescribed by the Codex. Thus, the sanitary and phytosanitary requirements are closely interlinked and cannot be treated as mutually exclusive, although there are different agencies dealing with them.

As already indicated, under the present international scenario, the plant protection organizations everywhere have a major role to play in maintaining biosecurity since they are responsible for facilitating export and import of goods and also for preventing introduction of invasion alien species. Also, they need to be prepared to thwart threats to national biosecurity from bioweapons. It is against this background, that FAO has included "biosecurity" in its sixteen priority areas for inter-disciplinary action. Biosecurity was also included in the Medium-Term Plan of FAO which aims at "promoting, developing and reinforcing policy and regulatory frameworks for food, agriculture, fisheries, and forestry" (FAO, 2003). ${ }^{12}$ Models to rationalize regulatory functions among sectors in the quest for improved efficiency have been formulated in a number of countries.

\section{THE WAY FORWARD}

As discussed above, the synergies of various sectors working on biosecurity at the national level needs to be fully harnessed to achieve better results. Also, priority should be attached to strengthen the existing biosecurity system in terms of legislation, infrastructure and technology. These interventions may create an empowered and integrated National Agricultural Biosecurity System (NABS) which can take care of all the biosecurity requisites of the country. The need of convergence of various Ministries and Departments to develop a suitable biosecurity strategy has been deliberated at the national level (Khetarpal and Gupta, 2007).

One of the other important requirements to maintain plant biosecurity in India is to set-up quarantine check-posts at inter-state borders manned by trained staff to control movement of plants, planting material and seeds through different pathways. Though Indian plant quarantine system has advanced significantly from the first legislation viz., Destructive Insects and Pests Act (1914), frequent updating of the quarantine regulations are crucial in the light of globalization of trade.

\footnotetext{
${ }^{12} \mathrm{http}: / /$ www.fao.org/3/Y8453e/Y8453e.htm
} 
Moreover, it is necessary that the biosecurity legislation addresses the forestry sector more diligently since the Govt of India has introduced the National REDD + Strategy under the Paris Agreement on Climate Change. The Govt is thus committed to address the causes of deforestation and forest degradation and develop plans for improving forest productivity, enhance carbon stocks and achieve sustainable management of forests. India has also declared that it will capture 2.5-3 billion tons of $\mathrm{CO}_{2}$ through additional forest and tree cover by 2030 (Government of India [GOI], 2018). ${ }^{13}$ Forest biosecurity needs to be implemented more scrupulously if these goals are to be realized.

India currently holds an internationally recognized forest certification scheme (NCCF) which mainly aims to promote sustainable management of forests and ensure market and public access to goods and services from forests including non-wood forest products (Network for Certification and Conservation of Forests [NCCF] India, 2015). ${ }^{14}$ There is no information so far how NCCF deals with forest pest management. However, meeting the objectives of NCCF also calls for proper enactment of the policy on forest biosecurity in India.

In 2013, an Agriculture Biosecurity Bill was proposed by Govt of India which aims to establish an Agricultural Biosecurity Authority to regulate import and export of plants and animals and related products, prevent the entry of quarantine pests and implement post-entry quarantine measures. The bill is expected to replace the Destructive Insects and Pests Act and the Livestock Importation Act. We suggest that the bill may include separate provisions to tackle threats to forest biosecurity. The bill is currently under consideration (Network for Certification and Conservation of Forests [NCCF] India, 2015). ${ }^{15}$

To summarize, the continuing threats to plant biosecurity in India indicate the inadequacy of the biosecurity legislation and the underperformance in its implementation. Various suggestions are included in this paper to improve the system and ensure proper implementation of regulations. These include

${ }^{13}$ https://pib.gov.in/Pressreleaseshare.aspx?PRID=1544484

${ }^{14}$ www.nccf.in

${ }^{15}$ https://www.prsindia.org/uploads/media/AgriculturalBiosecurity/

-LegislativeBrief.pdf

\section{REFERENCES}

Anderson, P. K., Cunningham, A. W., Patel, G. K., Morales, P. J., Epstein, P. R., and Daszak, P. (2004). Emerging infectious diseases of plants: pathogen pollution, climate change and agrotechnology drivers. Trends Ecol. Evol. 19, 535-544.

Banerjee, A. K., Khuroo, A. A., Dehnen-Schmutz, K., Pant, V., Patwardhan, V., Bhowmick, A. R., et al. (2021). An integrated policy framework and plan of action to prevent and control plant invasions in India. Environ. Sci. Policy 124, 64-72. doi: 10.1016/j.envsci.2021.0 6.003

Bhagwat, S. A., Breman, E., Thekaekara, T., Thornton, T. F., and Willis, K. J. (2012). A battle lost? report on two centuries of invasion and management of lantana camara L. in Australia, India and South Africa. PLoS One 7:e32407. doi: 10.1371/journal.pone.0032407

Bhalla, S., Chalam, V. C., Singh, B., Gupta, K., and Dubey, S. C. (2018). Biosecuring Plant Genetic Resources in India: Role of Plant Quarantine. New Delhi: ICARNational Bureau of Plant Genetic Resources. the need of revision and updation of the existing biosecurity legislation and improvement of the biosecurity infrastructure. In general, it is proposed that the country may formulate a national legislation/policy to address IAS exclusively and appoint a nodal agency to coordinate activities. Establishment of the National Agricultural Biosecurity System and an Agricultural Biosecurity Authority is expected to take care of the above suggestions including the need of a separate legislation for forest biosecurity. Hopefully, the Authority may also ensure strict execution of the updated legislations.

Some of the mandatory requirements to conserve plant biosecurity in India include periodic surveillance, detection and monitoring for alien pests in various ecosystems, scrupulous practice of pre-border, border, and post-border biosecurity measures and early detection and rapid eradication of IAS. India may also strengthen regional cooperation so as to harmonize regulations for sanitary, phytosanitary, and plant quarantine/biosafety measures and promote a common PRA system for pests unknown in the region.

It is proposed to adopt an IPM system to control the emerging pest threats which may involve e-pest surveillance, establishing pest-free areas, and biocontrol. The need of new technologies for bio-surveillance, forecasting, and monitoring of pests to assist management interventions is also raised. Joint efforts by the central and state Govts in implementing quarantine regulations, conforming with the international stipulations, would be more successful than acting in isolation. Also, capacity building of quarantine and customs officials to enable identification of risky goods and verification of conformity with Import Health Standards may be made mandatory. This will strengthen pre-border and border biosecurity measures. Raising awareness among stakeholders on the risks to biosecurity and involving them in IAS management activities are other important requirements.

\section{AUTHOR CONTRIBUTIONS}

KG collated part of the information. KS supplemented to it and edited the manuscript. Both authors agrees to the included text.

Bilodeau, E. S., Bo-Sen, W., Rufyikiri, A. S., MacPherson, S., and Lefsrud, M. (2019). An update on plant photobiology and implications for Cannabis production. Front. Plant Sci. 10:296. doi: 10.3389/fpls.2019.0 0296

Brown, J. K. M., and Hovmoller, M. S. (2002). Aerial dispersal of pathogens on the global and continental scales and its impact on plant disease. Science 297, 537-541.

Carnegie, A. J., Lawson, S., Wardlaw, T., Cameron, N., and Venn, T. (2018). Benchmarking forest health surveillance and biosecurity activities for managing Australia's exotic forest pests and pathogen risks. Aust. For. 81, 1 4-23.

Chakrabarty, S. K., Anitha, K., Girish, A. G., Sarath Babu, V., Prasada Rao, R. D. V. J., Varaprasad, R. K. S., et al. (2005). Germplasm Exchange and Plant Quarantine of ICRISAT Mandate Crops. Patencheru: ICRISAT.

Chowdhury, S., Hossain, M. E., Ghosh, P. K., Ghosh, S., Hossain, M. B., Beard, C., et al. (2019). The pattern of highly pathogenic avian influenza H5N1 outbreaks in South Asia. Trop. Med. Infect. Dis. 4:138. 
Cock, M. J. W. (2003). Biosecurity and Forests: An Introduction with Particular Reference to Forest Pests. Rome: FAO. FAO Forest Health and Biosecurity Working Paper FBS/2 E.

Convention on Biological Diversity [CBD] (2000). The Cartagena Protocol on Biosafety to the Convention on Biological Diversity, Text and Annexes. Montreal, MTL: CBD Secretariat.

Doane, C. C., and McManus, M. L. (1981). The Gypsy Moth: Research Toward Integrated Pest Management. Washington, D.C: USDA. USDA Forest Service Technical Bulletin 1584.

Ellison, C. A., Sankaran, K. V., and Murphy, S. T. (2017). Invasive AlienPlants: Impacts on Development and Options for Management. Wallingford: CABI.

FAO (2003). Committee on Agriculture, 17th Session, Biosecurity in Food and Agriculture, 31 March - 4 April, 2003. Rome: Food and Agriculture Organization.

FAO (2007). FAO Biosecurity Toolkit. Rome: Food and Agriculture Organization.

FAO (2011). International Plant Protection Convention. Secretariat of the IPPC. Rome: Food and Agriculture Organization.

Faulkner, K. T., Robertson, M. P., and Wilson, J. R. U. (2020). Stronger regional biosecurity is essential to prevent hundreds of harmful biological invasions. Global Change Biol. 26, 2449-2462. doi: 10.1111/gcb.15006

Fisher, M. C., Henk, D. A., Briggs, C. J., Brownstein, J. S., Madoff, L. C., McCraw, S. L., et al. (2012). Emerging fungal threats to animal, plant and ecosystem health. Nature 484, 186-194. doi: 10.1038/nature10947

Gautier, L. (1992). Taxonomy and distribution of a tropical weed: Chromolaena odorata (L.) R. King \& H. Robinson. Candollea 47, 645-662.

Government of India [GOI] (1992). The Destructive Insects and Pests Act, 1914 (Act No. II of 1914). Amended and Validated, 1992. New Delhi: Ministry of Agriculture and Farmers Welfare.

Government of India [GOI] (2003). The Plant Quarantine (Regulation of Import into India) Order, 2003, Directorate of Plant Protection, Quarantine \& Storage. Faridabad: Department of Agriculture \& Cooperation, Ministry of Agriculture and Farmers Welfare NH-IV.

Government of India [GOI] (2007). Status of Forest Invasive Species in India. New Delhi: Ministry of Environment, Forests and Climate Change.

Government of India [GOI] (2009). Intensification of Forest Management: Operational Guidelines, August 2009. New Delhi: Forest Protection Division, Ministry of Environment and Forests.

Government of India [GOI] (2011). Plant Quarantine Information System. User Manual for Importers and Exporters. Directorate of Plant Protection, Quarantine \& Storage. Faridabad: Department of Agriculture \& Cooperation, Ministry of Agriculture NH-IV.

Government of India [GOI] (2013). The Agriculture Biodiversity Bill, 2013, Legislative Brief. New Delhi: GOI.

Government of India [GOI] (2016a). Integrated Pest Management. Components of IPM. Directorate of Plant Protection, Quarantine \& Storage. Department of Agriculture \& Cooperation. Faridabad: Ministry of Agriculture and Farmers Welfare NH-IV.

Government of India [GOI] (2016b). Locust Control and Research. Desert Locust Situation Bulletins, Bimonthly, 16 October 2020 to 31 July 2021. Directorate of Plant Protection, Quarantine \& Storage. Faridabad: Department of Agriculture \& Cooperation, Ministry of Agriculture and Farmers Welfare, NH-IV.

Government of India [GOI] (2018). Press Information Bureau, Environment Minister's Releases India's National Redd+Strategy. New Delhi: Ministry of Environment, Forests and Climate Change.

Government of India [GOI] (2020). The Pesticide Management Bill, 2020. New Delhi: Ministry of Agriculture and Farmers Welfare, Agriculture and Rural Development, Bills in the Indian Parliament, PRS Legislative Research, Institute for Policy Research Studies.

Government of New Zealand (2018). Biosecurity New Zealand, Biosecurity Response Guide. Wellington: Ministry of Primary Industries.

Grünwald, N. J., Goss, E. M., and Press, C. M. (2008). Phytophthora ramorum: a pathogen with a remarkably wide host range causing sudden oak death on oaks and ramorum blight on woody ornamentals. Mol.Plant Pathol. 9, 729-740. doi: 10.1111/j.1364-3703.2008.0 0500.x

Gupta, K., and Agarwal, P. C. (2016). "Policies related to biosecurity in trade and exchange of germplasm in the context of plant health management," in Plant Health Management for Food Security Issues and Approaches, eds G. Katti, A.
Kodaru, N. Somasekhar, G. S. Laha, B. Sarath Babu, and K. S. Varaprasad (New Delhi: Astral International Pvt. Ltd.), 105-120.

Gupta, K., and Dubey, S. C. (2016). Regional collaboration for plant biosecurity in South Asian region. Indian Phytopathol. 69, 260-265.

Gupta, K., Gaur, A., and Khetarpal, R. K. (2005). "Role of regulatory measures in controlling spread of plant pests," in Integrated Pest Management: Principles and Application, eds O. P. Amerika Singh, D. Sharma, and K. Garg (New Delhi: CBS Publishers and Distributors).

Gupta, K., Kapur, M. L., and Khetarpal, R. K. (2007). "Safe transboundary movement of transgenic planting material," in Cartagena Protocol on Biosafety Decisions to Diagnostics, eds G. J. Randhawa, S. Bhalla, V. C. Chalam, and S. K. Sharma (New Delhi: National Bureau of Plant Genetic Resources), 57-73.

Gupta, K., and Khetarpal, R. K. (2004). Concept of regulated pests, their risk analysis and the Indian scenario. Ann. Rev. Plant Pathol. 3, 409-441.

Gupta, K., Chalam, V. C., Dev, U., and Khetarpal, R. K. (2009). “Global information on invasive alien species," in Invasive Alien Species- A Threat to Biodiversity, eds S. K. Sharma, R. K. Khetarpal, K. Gupta, and A. Lal (New Delhi: Indian Council of Agricultural Research, Ministry of Environment and Forests and National Biodiversity Authority), 39-54.

Hepting, G. H. (1974). Death of the American chestnut. J. For. Hist. 18, 61-67.

Invasive Species Council, Australia (2016). A Strategy for Dealing with Invasive Species in Australia, Govt. of Australia, Victoria. Available online at: https: //invasives.org.au/strategy-invasive-species-australia (accessed June 23, 2021).

Jacob, J. P., Devaraj, R., and Natarajan, R. (2007). Outbreak of the invasive gallinducing wasp Leptocybe invasa on eucalypts in India. Invasives Newsletter Asia-Pacific Forest Invasive Species Network (APFISN) 8, 4-5.

Jacobs, K., Wingfield, M. J., and Gibbs, J. N. (2004). "Pathology: vascular wilt diseases," in Encyclopedia of Forest Sciences, eds J. Burley, J. Evans, and J. A. Youngquist (Amsterdam: Elsevier).

Kahn, R. P. (1989). Plant Protection and Quarantine: Selected Pests and Pathogens of Quarantine Significance. Florida, FL: CRC Press Inc.

Kannan, R., Shackleton, M. C., and Shaanker, R. U. (2013). Playing with forest: invasive alien plant, policy and protected areas in India. Curr. Sci. 104, 11591165 .

Khetarpal, R. K. (2004). A critical appraisal of seed health certification and transboundary movement of seeds under WTO regime. Indian Phytopathol. 57, 408-427.

Khetarpal, R. K., and Gupta, K. (2002). Implications of sanitary and phytosanitary agreement of WTO on plant protection in India. Ann. Rev. Plant Pathol. 1, $1-26$.

Khetarpal, R. K., and Gupta, K. (2007). Plant biosecurity in India- Status and strategy. Asian Biotechnol. Dev. Rev. 9, 39-63.

Khetarpal, R. K., and Gupta, K. (2008). Plant quarantine in India in the wake of international agreements: a review. Rev. Plant Pathol. 4, 367-391.

Khetarpal, R. K., Balaraman, N., Bandopadhyay, S. K., Gupta, K., Jain, R. K., Kumar, J., et al. (2009). "Status of agricultural biosecurity," in State of Indian Agriculture, eds M. Rai, S. S. Acharya, S. M. Virmani, and P. K. Aggarwal (New Delhi: National Academy of Agricultural Sciences), 151-174.

Khetrapal, R. K., Gupta, K., Usha Dev, and Dashora, K. (2017). "Prevention and related measures for invasive alien plants in India: frame work and other initiatives," in Invasive Alien plants: Impacts on Development and Options for Management, eds C. A. Ellison, K. V. Sankaran, and S. T. Murphy (Wallingford: CABI International), 124-137.

Kishwan, J., Pandey, D., Goyal, A. K., and Gupta, A. K. (2007). India's Forests. Ministry of Environment and Forests. New Delhi: Govt of India.

Liebhold, A. M., Brockerhoff, E. G., Garrett, L. J., Parke, J. L., and Britton, K. O. (2012). Live plant imports: the major pathway for forest insect and pathogen invasions of the US. Front. Ecol. Environ. 10:135-143. doi: 10.1890/110198

McCook, S. (2006). Global rust belt: Hemileia vastatrix and the ecological integration of world coffee production since 1850. J. Glob. Hist. 1, 177-195. doi: $10.1017 / \mathrm{S} 174002280600012 \mathrm{X}$

Meng, P. S., Hoover, K., and Keena, M. A. (2015). Asian longhorned beetle (Coleoptera: Cerambycidae), an introduced pest of maple and other hardwood trees in North America and Europe. J. Integr. Pest Manage. 6:4. doi: 10.1093/ jipm/pmv003

Meurisse, N., Rassati, D., Hurley, B. P., Brockerhoff, E. G., and Haack, R. A. (2019). Common pathways by which non-native forest insects move internationally and domestically. J. Pest Sci. 92, 13-27. doi: 10.1007/s10340-018-0990-0 
Mohandas, K., Mathew, G., Nair, K. S. S., and Menon, A. R. R. (1990). "Pest incidence in natural forests - a study in moist deciduous and evergreen forest of India," in Proceedings of the Pests and diseases of forest plantations in the Asia-Pacific Region. Proceedings of the IUFRO Workshop, (Rome: FAO), $129-134$.

Network for Certification and Conservation of Forests [NCCF] India (2015). Brief about NCCF, New Delhi. Available online at: https://www.nccf.in (accessed June 23, 2021)

Peh, K. S.-H. (2010). Invasive species in Southeast Asia: the knowledge so far. Biodivers. Conserv. 19, 1083-1099.

Pyšek, P., Hulme, P. E., Simberloff, D., Bacher, S., Blackburn, T. M., Carlton, J. T., et al. (2020). Scientists' warning on invasive alien species. Biol. Rev. 9, 1511-1534. doi: 10.1111/brv.12627

Rana, R. S., Dhillon, B. S., and Khetarpal, R. K. (2004). Invasive alien species: the Indian scene. Indian J. Plant Gen. Resources 16, 190-213.

Sankaran, K. V., and Suresh, T. A. (2013). Invasive Alien Plants in the Forests of Asia and the Pacific. Bangkok: Food and Agriculture Organization, Regional Office for Asia and the Pacific.

Sankaran, K. V., Suresh, T. A., and Sajeev, T. V. (2013). Handbook on Invasive Plants of Kerala. India: Kerala State Biodiversity Board.

Santini, A., Ghelardini, L., De Pace, C., Desprez-Loustau, M. L., Capretti, P., Chandelier, A., et al. (2013). Biogeographical patterns and determinants of invasion by forest pathogens in Europe. New Phytol. 197, 238-250. doi: 10.1111/ j.1469-8137.2012.04364.x

Saville, A. C., Martin, M. D., and Ristaino, J. B. (2016). Historic late blight outbreaks caused by a widespread dominant lineage of Phytophthora infestans (Mont.) de Bary. PLoS One 11:e0168381. doi: 10.1371/journal.pone.016 8381

Sharma, J. K., Mohanan, C., and Florence, E. J. M. (1985). Disease Survey in Nurseries and Plantations of Forest tree Species Grown in Kerala. India: Kerala Forest Research Institute. KFRI Research Report.
Singh, A. P., Bhandari, R. S., and Verma, T. D. (2004). Important insect pests of poplars in agroforestry and strategies for their management in northwestern India. Agrofor. Syst. 63, 15-26. doi: 10.1023/B:AGFO.0000049429.37483.47

Sturrock, R. N., Frankel, S. J., Brown, A. V., Hennon, P. E., Kliejunas, J. T., Lewis, K. J., et al. (2011). Climate change and forest diseases plant pathol. special issue. Climate Change Plant Dis. 60, 133-149. doi: 10.1111/j.1365-3059.2010.0 2406.x

US Department of Agriculture [USDA]-Animal and Plant Health Inspection Service [APHIS] (2020). Plant Pest and Disease Programs. Washington, D.C: USDA.

Valenta, V., Moser, D., Kapeller, S., and Essl, F. (2016). A new forest pest in Europe: a review of Emerald ash borer (Agrilus planipennis) invasion. J. Appl. Entomol. 141, 507-526. doi: 10.1111/jen.12369

Wardlaw, C. W. (1961). Banana Diseases, Including Plantains and Abaca. London: Longman, Green and Co Ltd., 648.

Conflict of Interest: The authors declare that the research was conducted in the absence of any commercial or financial relationships that could be construed as a potential conflict of interest.

Publisher's Note: All claims expressed in this article are solely those of the authors and do not necessarily represent those of their affiliated organizations, or those of the publisher, the editors and the reviewers. Any product that may be evaluated in this article, or claim that may be made by its manufacturer, is not guaranteed or endorsed by the publisher.

Copyright (C) 2021 Gupta and Sankaran. This is an open-access article distributed under the terms of the Creative Commons Attribution License (CC BY). The use, distribution or reproduction in other forums is permitted, provided the original author(s) and the copyright owner(s) are credited and that the original publication in this journal is cited, in accordance with accepted academic practice. No use, distribution or reproduction is permitted which does not comply with these terms. 